\title{
Aristotelés a Platónova diairese ${ }^{\mathrm{i}}$
}

\section{Jan Prokeš}

V rámci Aristotelovy přírodní filosofie bývá přisuzována stěžejní role první knize spisu $O$ částech zvířat (Peri zoión morión; De partibus animalium; dále $P A)$. Aristotelés v ní ustavuje metodologii př́rodovědního zkoumání, včetně možností klasifikace živočišné říše. Tři z pěti kapitol první knihy $P A$ se zabývají problematikou adekvátního dělení individuí s různými vlastnostmi. Pozitivní vymezení žádoucí metodologie (vrcholící ve 4. kap.) provázejí negativní pasáže (zvl. ve 2. a 3. kap.), v nichž Aristotelés kritizuje metodu dichotomního rozdělování vycházející z platónské dialektiky (tzv. metodu diairese). ${ }^{\text {ii }}$

V následujícím textu se budu zabývat právě diairesí a Aristotelovým negativním vymezením vůči ní. $V$ první části nejprve načrtnu hlavní principy dichotomního rozdělování; následně se zaměřím na jádro Aristotelovy kritiky a určitá specifika jeho metodologického uvažování. Poté se vrátím ke kontextu, v němž dichotomní dělení používá Platón, a pokusím se obnažit rozdíly mezi tím, jak oba jmenovaní myslitelé vnímají úlohu vhodné metody v rámci svých filosofických intencí.

\footnotetext{
i Článek vznikl na základě př́spěvku předneseného na konferenci Filosofie přírody mezi aristotelismem a darwinismem (Olomouc, FF UP, 2. prosince 2012) a je jedním z výstupů Studentské grantové soutěže UP, č. p. FF_2011_034.

ii Stručná charakteristika Platónovy diairese, včetně nastínění jejího pravděpodobného vývoje i Aristotelovy kritiky, viz Guthrie 1978, s. 129-134.
} 


\section{Aristotelés}

Aristotelova kritika dichotomního rozdělování vystupuje v kontextu otázky, jak stanovit základní metodologii vhodného rozčleňování živočišných druhů. Z moderního hlediska jde vlastně o problematiku biologické taxonomie. Jak si však všímá komentátor David Balme, ${ }^{i}$ u Aristotela tato otázka úzce souvisí s metodologií korektního definování, protože podmínkou pro určení jednotlivých druhů je jejich náležité rozdělení do nadřazených rodů a vymezení prostřednictvím specifických rozdílů.

Problém tkví v tom, že živočišnou řiši tvoří soubor druhů s velmi pestrým repertoárem vlastností, které se navzájem spletitě překrývají. To ztěžuje volbu vlastnosti, která by jako specifická diference posloužila $k$ jednoznačnému vymezení toho či onoho druhu. Aristotelova teze zní, že za takové situace nemůžeme jednotlivé druhy vyčleňovat $z$ daného souboru ( $v$ tomto případě živočišné řišse) za pomoci jediné specifické vlastnosti, nýbrž celé množiny diferencí.

Aby názorně ukázal, proč je takový postup jediným legitimním řešením, poukazuje na problémy, jimž čelí alternativní př́stup, představovaný již zmiňovanou metodou podvojného dělení (diairese). Jakým způsobem Ize dichotomní dělení uplatnit v rámci procesu definování a $z$ něho vycházející klasifikace určitého souboru entit, ilustrativně ukazují Platónovy dialogy Sofistés a Politikos. Tyto dialogy se sice primárně nezabývají definováním či klasifikací živočichů, ale částečně se této problematiky dotýkají a pravděpodobně sloužily jako paradigma, o které se opírala zoologická

i Balme 2003, s. 104 nn. 
klasifikace prováděná v rámci Akademie, vůči níž se Aristotelés svou kritikou vymezuje.

Metoda dichotomního dělení praktikovaná v Sofistovi a Politikovi spočívá v následujícím postupu:ii

1) Definovaný pojem je identifikován jako prvek podstatně širší množiny (např. rybář-udičník: spadá pod množinu „lidí, kteří disponují techné“, viz Sof. 219a).

2) Širší množina je rozdělena do dvou zhruba stejně obsáhlých podmnožin (techné může být získávací, nebo tvořivé, viz Sof. 219d).

3) Je identifikována podmnožina, do níž spadá definovaný pojem (techné rybáře-udičníka spadá pod techné získávací, viz Sof. 219d). V případě, že je tato podmnožina (získávací techné) širší než sám vymezovaný pojem (techné rybáře-udičníka), je opět rozdělena do dvou zhruba stejně obsáhlých podmnožin (výměnné vs. zmocňovací techné, viz Sof. 219d). Takto se postupuje rekurzivně dál, dokud není získána podmnožina kryjící se s obsahem definovaného pojmu.

Aristotelova kritika popsaného postupu se zaměřuje na problémy, které vyvstávají při jeho aplikaci na zoologii, resp. na klasifikaci zvířecích druhů. Jak si však všímá David Balme,iii Aristotelovu kritiku Ize zobecnit. Ukazuje totiž, že dichotomní dělení selže kdykoliv, když se potýká s rozdělováním

i Podrobněji viz níže - poznámky č. 8-10.

ii Detailnější analýza viz Philip 1966.

iii Balme 2003; s. 105. 
souboru objektů majících natolik komplexní vlastnosti, že je nelze hierarchicky rozdělovat na základě jediného kritéria.

Právě v tom spočivá podle Aristotela největší slabina dichotomního dělení. Má-li být tento postup systematický, a nikoli nahodilý, musí být ve všech rozčleňujících krocích prováděn se zřetelem k určitému jednotícímu rysu, který všechny bifurkace sjednocuje. Pokud například zviŕata rozdělíme na beznohá (jako jsou ryby) a mající nohy, nemůžeme „nohaté“ živočichy dále členit na krotké a divoké. Zavádíme tím totiž nové rozlišující kritérium, jež s tím původním nijak nesouvisí a vystavuje nás riziku dělení na základě arbitrárních, nikoli esenciálních vlastností (srov. PA 643b19-26). Zviŕata mající nohy tak můžeme legitimně rozdělit napríklad na dvounohá (ptáci, člověk) a vícenohá - a na ně uplatnit další kritéria související např. s počty prstů na nohou, jež zůstávají průvodním znakem původního kritéria („,nohatosti“). Dříve nebo později však podle Aristotela vždycky dojdeme do slepé uličky, v níz již nebudeme moci dále rozčleňovat s ohledem na výchozí kritérium. $V$ takovém prípadě budeme bud' nuceni dichotomní členění ukončit, aniž bychom však rozdělili zviřrecí druhy vyčerpávajícím způsobem, nebo budeme muset použít nové, dodatečné kritérium, které nebude zahrnuté v původním, a dělení ztroskotá na arbitrárnosti. Dichotomní dělení bude tedy vždy bud' neúplné, nebo nahodilé, resp. nekonsekventní, nesystematické.

Nevyhnutelnost tohoto konce je podle Aristotela dána zejména tím, že dichotomisté nedokáží předejít tomu, aby jako vymezující znak uplatňovali privaci (viz PA 642b21-643a27): proti zviřatům s nohami staví zvírata beznohá, proti pernatým zviŕata bez peří, proti „krevnatým“ "bezkrevná“ (jako hmyz). Privace však není vlastnost, která by umožňovala další členění. 
Zatímco „krevnatá“ zviřata můžeme napríklad rozdělit na "horkokrevná“ či „studenokrevná“, „bezkrevná“ zviŕrata již dále rozčleňovat nelze. „Bezkrevnost“ je totiž čistě negativní vymezení, nikoli vlastnost, která by měla další charakteristiky, pomocí nichž by bylo možné v dělení pokračovat.

To, že je kritérium dělení limitováno na jediný vymezující rys, s sebou navíc přináší nutnost násilné simplifikace, jejímž důsledkem je nerespektování přirozených zviř̌ecích rodů. Základní dichotomní členění, které najdeme i v Platónově Sofistovi, napríklad rozděluje zviŕata na vodní a suchozemská; mezi oběma těmito kategoriemi však figurují ptáci (na jednu stranu suchozemští, na druhou stranu vodní: kachny ap.). Tím dochází k rozštěpení rodu ptáků do dvou protichůdných skupin, které - tím, že jsou postaveny proti sobě prakticky na začátku dělení, tedy hierarchicky nejvýše - by měly být fundamentálním způsobem odlišné. Ve skutečnosti však vodní $\mathrm{i}$ suchozemské ptáky spojuje celá řada zásadních podobností (homoioi, viz PA 242b15), které jsou natolik markantní, že pro tuto skupinu zviřat mají lidé souhrnné pojmenování: ptáci. Její štěpení je pro Aristotela natolik nepřirozené a absurdní, že o něm hovoří jako o něčem pošetilém (mataios, PA 242b19).

Tento bod Aristotelovy kritiky je zcela příznačný. Ptáci jsou natolik zřejmým samostatným rodem, že si získali souhrnné pojmenování. Tím, co ustavuje status ptáků coby živočišného rodu, není samozřejmě samo pojmenování, nýbrž souhrn podobných vlastností (homoioi). Sama existence souhrnného pojmenování však představuje pro Aristotela signál, který by nás měl před rozštěpováním množiny ptáků varovat. Aristotelés tedy používá konvencionalizovaný charakter pojmenování jako doprovodnou evidenci pro svůj argument, který se tím vlastně dovolává obecně přijímaného, 
v běžné komunikaci ukotveného mínění - endoxa (dnes bychom snad mohli rríci „common sense“). Jak si všímá Martha Nussbaumová, 'Aristotelés často chápe endoxa jako určité vodítko svých zkoumání, čímž se samozřejmě výrazně odlišuje od Platóna, který k obecným míněním přistupuje s notnou dávkou nedůvěry a pochybnosti.

Na základě dosavadních poznámek si tak můžeme udělat určitý obrázek o tom, na co Aristotelés v rámci metodologických úvah klade důraz. Jde mu o metody univerzálně uplatnitelné, systematické, které vyloučí prvek nahodilosti a budou respektovat přirozený stav věcí, přičemž si zároveň zachovají určitou uživatelskou intuitivnost, tzn. nebudou se výrazně rozcházet s common sense (endoxa). Ve všech těchto bodech dichotomní dělení podle Aristotela selhává. Je však třeba se ptát, zda tato metoda nemá v platónském kontextu plnit poněkud odlišné poslání, než proti kterému Aristotelés útočí.

\section{Platón}

Aristotelés dichotomní diairesi chápe podle všeho jako pokus o univerzální metodu definování či klasifikace, která má ambice sehrát významnou roli voblasti zoologických zkoumání. Takovou úlohu však diairesi nelze na základě Platónových dialogů jednoznačně přisoudit. Proto se často spekuluje o tom, že Aristotelés svou kritikou reaguje spíše na Speusippaii či

i Nussbaumová 2003, s. 469-509.

ii Viz Guthrie 1978, s. 132. Speusippos napsal podle Diogena Laertského (Životy, názory a výroky proslulých filosofü, IV, 4-5) mimo jiné pojednání Diairesis kai pro 
jiné členy Akademie než prímo na Platóna.i At' už však diairese praktikovaná Platónovými žáky skutečně usilovala o zoologickou taxonomii, nebo ne, formálním vzorem pro ni podle všeho bylo dichotomní dělení prováděné v dialozích Sofistés a Politikos. Alespoň část Aristotelových narážek a argumentů je s největší pravděpodobností cílena právě na diairesi v těchto dvou textech.ii

Dichotomní dělení v Sofistovi a Politikovi vystupuje jako metoda používaná k definování; je však sporné, zda v tom spočívá její jediný či hlavní cíl. Získávání definic prostřednictvím dichotomního dělení je dosti komplikované a sám Platón naznačuje, že tento postup nemusí vést napoprvé ke zcela uspokojivému výsledku. V Sofistovi je např́klad postupně předložena celá série možných definic sofistického umění, z nichž teprve poslední, v pořadí sedmá, je podle všeho pokládána za adekvátní. Předchozí definice slouží pouze jako východiska čím dál komplexnějších filosofických úvah, jež proces definování pojmu „sofista“ provázejí.

Celá anabáze začíná tím, že hlavní mluvčí dialogu, Host z Eleje, nejprve s pomocí dichotomního rozčleňování definuje rybáře-udičníka (218e-221c). Toto vymezení poslouží jako vzorový příklad a zároveň jako východisko pro hledání definice sofisty. Zahajovací pokus o vymezení sofistického umění

ta Homoia Hypothesis (Rozděleni a podklady v podobnosti; snad jde o spis navazující na titul Podobnosti - Homoia) a Peri genón kai eidón paradeigmatón (O príkladech rodů a druhů). Právě o těchto titulech se někdy soudí, že by mohly být terčem Aristotelovy kritiky. Nemáme z nich však dochován žádný fragment, který by tyto spekulace potvrdil. Viz Balme 2003, s. 108. Srov. též Dillon 2003, s. 36.

i K této možnosti se přiklání i Balme 2003 (s. 108), který však připouští, že se Aristotelova kritika Platónových dialogů přinejmenším dotýká (s. 102).

ii Obsáhlejší argumentaci pro přímou souvislost Aristotelovy kritiky s dialogy Sofistés a Politikos předkládá Lennox 2004, s. 152 n. a 166. 


\section{AIOIIP 7. /2013}

dokonce prímo naváže na definici rybáře-udičníka, protože sofistika je podobně jako rybářství identifikována jako určitý druh loveckého umění (221d-e). První definice sofisty se tak vlastně ukáže být jen další větví navázanou na bifurkační strukturu, z níž rezultovala definice rybářeudičníka. Rovněž ostatní definice se pouze na různých místech vřazují do již započatého větvení. Při tom se v nich někdy uplatňují stejná rozčleňující kritéria jako v ostatních větvích, ale užívají se k rozdělování odlišných druhů umění. Opakuje se např́klad rozlišování mezi veřejným a soukromým charakterem techné, které je aplikováno jak na umění přesvědčovací ( $v$ rámci 1. definice sofisty), tak na umění slovního zápasu (v rámci 5. definice); oba typy umění přitom spadají do odlišných definičních větví a neodpovídají si ani svou hierarchickou pozicí v diairetickém řetězci.

Z pohledu Aristotela by už sama pluralita takto získaných definic a zejména uplatňování týchž rozdělujících kritérií v různých souvislostech mohlo být důkazem chaotičnosti celé metody. Pro Platóna se však v tomto chaosu začíná rýsovat cesta $\mathrm{k}$ cíli. Jednotlivá vymezení jsou díky provázanému větvení či uplatňování stejných rozčleňujících kritérií (byt' v různých souvislostech) propojena řadou analogií, které spolu se strukturovanou podobou definic umožňují jejich průběžné srovnávání a další rozvíjení, resp. zpřesňování. Např. první definice zdůrazňuje výdělečný charakter činnosti sofistů (což je rys, který se prolíná i následujícími vymezeními);ii ale neupřesňuje, sčím vlastně sofisté obchodují. To se postupně vyjasňuje vdalších definicích - jde o obchod surčitým typem nauk vážících se

i Srov. Sayre 2006, s. 62-65.

ii S výjimkou definice „ušlechtilé sofistiky“, která je nejspíše popisem sókratovského elenchu a je naznačeno, že nejde o sofistiku ve vlastním smyslu (viz Sof. 230e-231c); srov. Sayre 2006, s. 65-67. 
k provozování rétorické činnosti, konkrétně ke slovnímu zápasnictví, jehož základ je odhalen ve schopnosti vytvářet iluzi vědění. Tento poznatek slouží jako impuls $k$ další diskuzi. Jejím plodem je nejen finální definice sofisty jako určitého typu padělatele pravdy, ale také rozkrytí řady filosofických problémů, které s sebou takové pojetí přináší - jako je třeba otázka možnosti existence nejsoucna či pronášení výroků o nejsoucích věcech.

Zdá se tedy, že diairese má v kontextu dialogu Sofistés spíše povahu heuristického procesu postupného vyjasňování podstaty nejednoznačného pojmu. $V$ tomto procesu nejde jen o samotnou finální definici, ale i o samu proceduru jejího hledání, na niž se nabalují čím dál složitější filosofické úvahy. Diairese tak plní roli stimulu a vodítka filosofické diskuze. Její hlavní výhodou je, že pracuje s řetězci významových vztahů mezi jednotlivými pojmy, resp. pojmovými druhy (eidé, srov. Pol. 285a4). Tyto řetězce představuji přehledné struktury vhodné $\mathrm{k}$ dalšímu porovnávání a rozvíjení. Klíčový je v tomto procesu zřejmě právě moment srovnání, tedy na jednu stranu hledání odlišností, na druhou stranu odhalování analogií, na který se klade explicitní důraz v Politikovi 285a-b.i Komparativní moment umožňuje

i Ale i ve Faidrovi 265e-266b, v němž je diairese zřejmě poprvé explicitně představena.

ii Komparace probíhá na několika úrovních. Za prvé $\mathrm{k}$ ní př́iležitostně dochází už v průběhu samotného procesu rozčleňování (např. v rámci definice „ušlechtilé sofistiky“" se rozděluje nejen pravá, ale i levá strana větveného schématu, přičemž obě strany jsou jakýmisi zrcadlovými protějšky: technai pečující o tělo skýtají analogie k technai pečujícím o duši a usnadňují jejich rozlišení). Za druhé se provádí vzájemná komparace různých diairetických schémat coby celků (šest prvních definic sofisty je shrnuto a je z nich vybrán pouze nejrelevantnější rys, tj. sofistika jako eristické zápasení za pomoci nápodoby vědění). A za třetí dochází k porovnávání jednotlivých diairetických schémat s jejich paradeigmaty (tj. „cvičnými“, resp. vzorovými definicemi), jež jsou chápány jako analogie definic hledaného pojmu (rybář-udičník - sofista; tkadlec - politik). Každá z těchto komparací stimuluje úsilí 


\section{AIOIIP 7./2013}

celou proceduru posouvat na další a další úrovně, a tím nejen dospívat k čím dál propracovanějším definicím, ale i rozkrývat čím dál složitější filosofické problémy a zdokonalovat cit pro jejich řešení, tedy samu dialektickou dovednost.

Tomu odpovídá skutečnost, že úvaha o důležitosti komparace, resp. poměřování různosti a stejnosti, která zaznívá v Politikovi 285a-b, tvoří zároveň most $\mathrm{k}$ přehodnocení dosavadní podoby diairese. Ta už dále není praktikována jako striktně dichotomní dělení, ale připouští rozčleňování do vícečetných skupin, které má být vedeno zřetelem k respektování přirozených složek definovaného pojmu. ${ }^{i}$ Proč dochází k náhlé rezignaci na čistě dichotomní postup? Hlavní mluvčí dialogu, Host z Eleje, krátce před tímto krokem zdůrazní, že možnost podat adekvátní pojmový výklad je podmíněna neustálým cvičením intelektuálních schopností, tedy rozvojem dialektických dovedností (srov. 286a). Dialogy Sofistés a Politikos slouží podle všeho jako ukázka či prototyp takového výcviku. Heuristická povaha metody diairese, která je v nich praktikována, umožňuje pozvolný nárůst přesnosti hledaných definic, ale také komplexnosti úvah, které vyvolává rozkrývání vztahů totožnosti a různosti. Tím dochází i k tř́bení dialektického citu, k nárůstu dialektické zdatnosti. Na určité úrovni celého procesu, když se již naše dialektické schopnosti dostatečně vytř́bily, můžeme tedy zřejmě mechanické dichotomní dělení opustit ve prospěch náročnějšího, zato ovšem pružnějšího dělení do většího počtu skupin.

o větší subtilnost dělení, případně určuje jeho další směr či vede k přehodnocení dosavadních definic.

i Dělení má probíhat kat'eidé (285a), resp. kata melé (287c). 


\section{AIOIIP 7./2012}

Pokud jsou výše naznačené úvahy správné, pak ambicí Platónovy diairese nebylo ani tak vytvořit neprůstřelnou metodu definování či klasifikace pojmů, nýbrž spíše spojit moment dialektického bádání s pedagogickocvičnými motivy. Diairese nemůže dostát požadavku metody ve smyslu ustáleného souboru neměnných, univerzálně použitelných postupů. Spíše se zdá být pokusem o heuristicko-pedagogický mechanismus, který usiluje o postupnou optimalizactahů mezi náročností metody, dialektickou úrovní jejího uživatele a povahou zkoumaného předmětu. Zhuštěně by se tak rozdíl mezi Aristotelovými a Platónovými cíli dal shrnout do konstatování, že zatímco Aristotelés spatřuje klíč kodbornému bádání v univerzálním charakteru vědecké metody, Platón jej hledá v rozvoji individuálních schopností odborníků. 


\section{Bibliografie:}

Balme, D. M. (trans., kom.), 2003, De Partibus Animalium and De Generatione Animalium I, Oxford.

Burnet, J. (ed.), 1900-1907, Platonis Opera I-V, Oxford.

Diogenés Laertios, 1995, Životy, názory a výroky proslulých filosofů, Pelhřimov.

Page, T. E. (ed.), 1961, Aristotle - Parts of Animals. Movement of Animals. Progresion of Animals, London.

Lennox, J. G. (trans., kom.), 2004, On the Parts of Animals, Oxford.

Platón, 2000, Faidros, Praha.

Platón, 2009, Politikos, Praha.

Platón, 2005, Sofistés, Praha.

Guthrie, W. K. C., 1978, A History of Greek Philosophy. Vol. V: The Late Plato and the Academy, Cambridge.

Dillon, J., 2003, The Heirs of Plato. A Study of the Old Academy (347-274 B. C.), Oxford.

Nussbaumová, M. C., 2003, Křehkost dobra, Praha. 
Sayre, K., 2006, Metaphysics and Method in Plato's Statesman, Cambridge.

Philip, J. A., 1966, „Platonic Diairesis“, Transactions and Proceedings of the American Philological Association 97, s. 335-358. 


\section{Abstrakt}

Autor se v článku nejprve formuluje cíl Aristotelovy metodologie: obecně aplikovatelné postupy, umožňující nutné závěry při respektu k přirozenosti zkoumaných předmětů i $\mathrm{k}$ jejich běžnému zakotvení $v$ common sense. Platónská metoda diarese tyto nároky nesplňuje. $V$ zoologických spisech ji totiž Aristotelés chápe jako neúspěšný pokus o universální klasifikační metodu. Aristotelova kritika ale podle Prokeše přehlíží, že Platónovi nejde v prvé řadě o definici jako odpověd' na výchozí otázku, ale o sám proces hledání, kultivující dialektickou dovednost.

\section{Abstract}

The author formulates the first goal of Aristotle's methodology generally applied procedures, allowing the necessary conclusions with respect to the nature of the examined subjects as well as their usual rooted in common sense. Platonic method DIARES these demands are not met. In zoological writings of Aristotle understands it is a failed attempt at universal classification method. Aristotle's criticism but by Prokes overlooked that Plato is not primarily concerned with the definition as an answer to the initial question, but the very process of finding, cultivating dialectical skill. 